\title{
DESIGN AND OPTIMISATION OF FUEL TANKS FOR BWB CONFIGURATIONS
}

This paper describes assumptions, goals, methods, results and conclusions related to fuel tank arrangement of a flying wing passenger airplane configuration. A short overview of various fuel tank systems in use today of different types of aircraft is treated as a starting point for designing a fuel tank system to be used on very large passenger airplanes. These systems may be used to move fuel around the aircraft to keep the centre of gravity within acceptable limits, to maintain pitch and lateral balance and stability. With increasing aircraft speed, the centre of lift moves aft, and for trimming the elevator or trimmer must be used thereby increasing aircraft drag. To avoid this, the centre of gravity can be shifted by pumping fuel from forward to aft tanks. The lesson learnt from this is applied to minimise trim drag by moving the fuel along the airplane. Such a task can be done within coming days if we know the minimum drag versus CG position and weight value. The main part of the paper is devoted to wing bending moment distribution. A number of arrangements of fuel in airplane tanks are investigated and a scenario of refuelling - minimising the root bending moments - is presented. These results were obtained under the assumption that aircraft is in long range flight (14 hours), $C_{L}$ is constant and equal to 0.279 , Specific Fuel Consumption is also constant and that overall fuel consumption is equal to 20 tons per 1 hour. It was found that the average stress level in wing structure is lower if refuelling starts from fuel tanks located closer to longitudinal plane of symmetry. It can influence the rate of fatigue.

\section{Nomenclature}

PDA - Passenger Driven Aircraft (三 flying wing configuration)

BWB - Blended Wing Body

VELA - Very Efficient Large Aircraft (European FPVI Project)

alpha - Angle of attack [deg]

$c, c_{A} \quad$ - Wing local chord; Wing Mean Aerodynamic Chord

\footnotetext{
${ }^{1}$ Warsaw University of Technology.Email: goraj@meil.pw.edu.pl
} 


$\begin{array}{ll}C_{L} & - \text { Lifting force coefficient } \\ C_{D} & - \text { Drag force coefficient } \\ \text { STB } & \text { - Software for trim and stability analysis } \\ b & - \text { Wing span } \\ \text { CG } & \text { - Centre of gravity } \\ \text { MAC } & - \text { Mean Aerodynamic Chord }[\mathrm{m}] \\ F & - \text { Normal force } \\ M & - \text { Bending moment } \\ V & - \text { Shear force } \\ Q & - \text { Weight of the structure } \\ L & - \text { Lift force } \\ W=L-Q & - \text { Loading force }\end{array}$

\section{Overwiew}

Integral tanks [1] are cavities within the airframe structure that are sealed to form a fuel tank. Ideally, an integral tank would be created simply by sealing the existing structures such as wing boxes. Integral wing tanks came into use when aircraft structures had become more stiff due to requirements of higher flight performance in 1950s. The use of carbon-fibre composites has provided complex shaped integral fuselage tanks with the advantage of increasing fuel capacity by 10 to $15 \%$. Evolution of fuel tanks in fighters is shown in Fig. 1 on an example of Mystere B2 (flexible tanks), Mirage IIIE (integral wing, flexible fuselage) and Mirage 2000 (integral tanks).

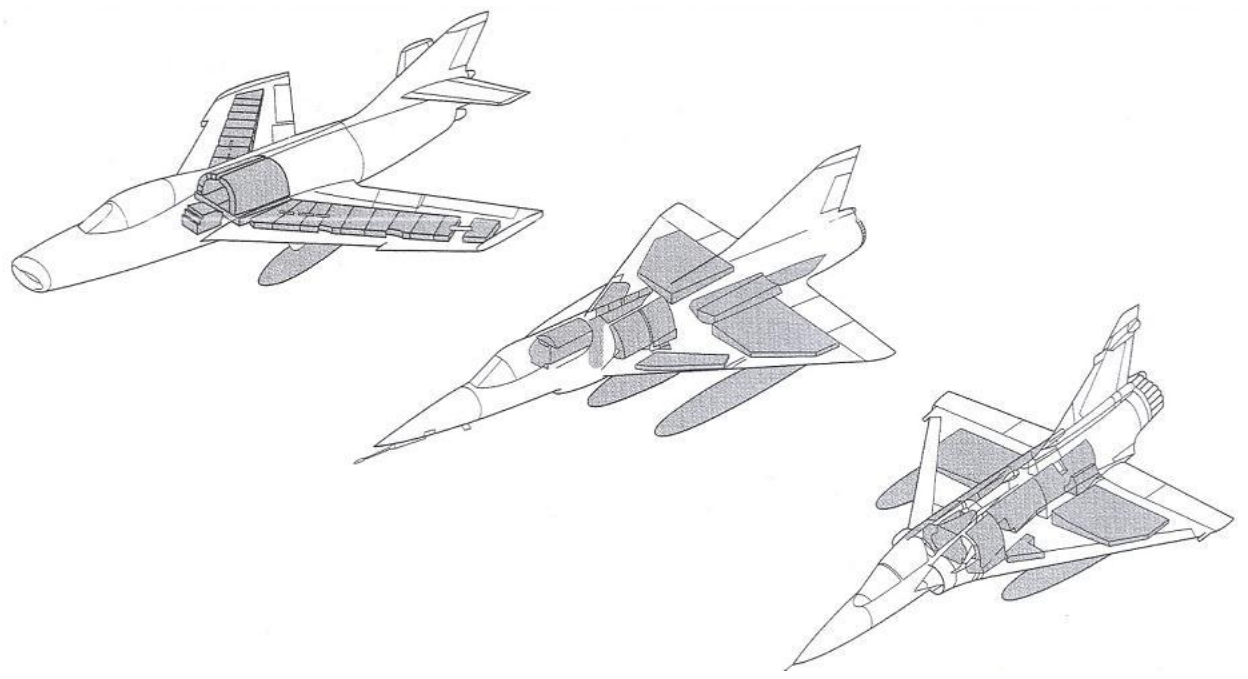

Fig. 1. Evolution of typical fuel tank layouts in military aircrafts [2] 
The aircraft might need a fuel tank control system to maintain the correct CG position. Such a system is described in the following example when trim tank is used to control location of CG during normal airliner operation.

The fuel transfer system controls the CG of the aircraft. When the aircraft is in cruise, the system optimizes the CG position to increase the fuel economy by reducing the drag of the aircraft. The system transfers fuel to the trim tank or from the trim tank, Fig. 2. This movement of fuel changes the CG of the aircraft. Normal operation is automatic but the crew can manually control fuel transfer.

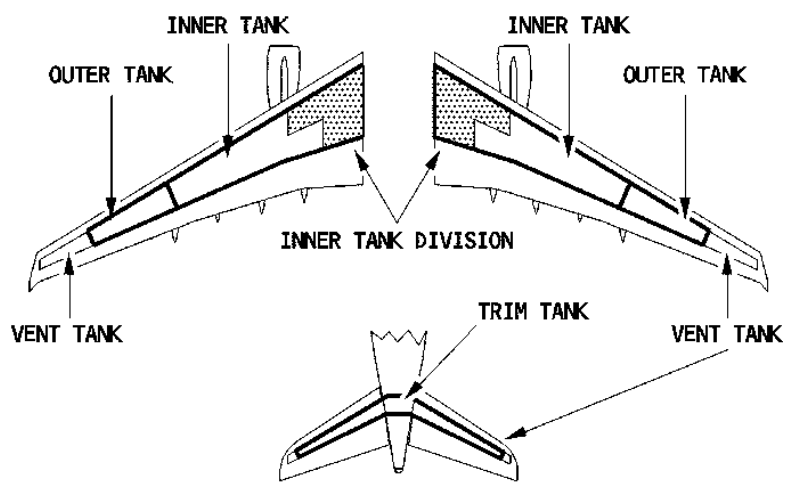

Fig. 2. Fuel tanks location of example airliner [3]

The flight management computer (FMC) calculates the CG of the aircraft and compares the result to a target value. From this calculation, the FMC decides the quantity of fuel to be moved aft or forward in flight (usually only one aft fueltransfer is carried out during each flight). Such a kind of the fuel transfer system was just considered and analysed for NACRE flying wing configuration [4].

Another example is CG control during supersonic flights of Concorde, Fig. 3. Concorde has multiple fuel tanks. During the flight, fuel is transferred from tank

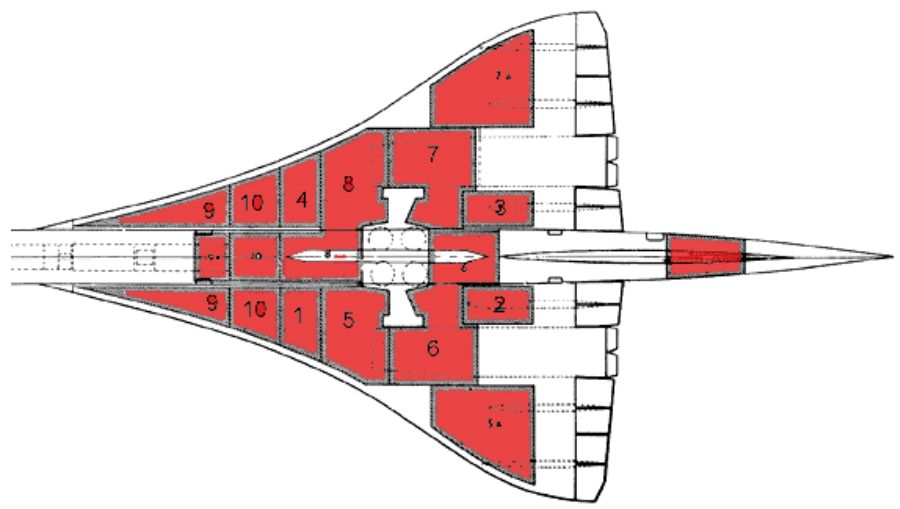

Fig. 3. Location of Concorde's fuel tanks [5] 
to tank to maintain trim and balance of the aircraft as it does not have a full tail plane which would be used on a subsonic airliner to perform this task. Also for supersonic flight, the Centre of Gravity is critical and required to be moved for different speeds.

In open literature, there is no wide description of fuel tank configurations, solutions and optimizations. One of a few positions devoted to fuel tanks design is the monograph edited by AIAA in 2010 [6]. A number of papers are devoted to selected aircraft where specific solutions are presented, mainly from the points of view of final arrangement, without details reflecting preliminary analyses and without discussion why just such solutions were chosen, see [3, 5, 7-13]. An analysis of the influence of fuel tank empting on a trimming and stability for a high aspect ratio UAV wing was prepared within FP5 CAPECON project [14, 15]. Many detailed analyses devoted to optimization of fuel tanks for BWB passenger aircraft were performed under the umbrella of FP6 NACRE project, where influence of longitudinal and lateral arrangement of fuel tanks was analysed and optimized, see $[4,16]$.

\section{Tank layout and bending moments}

This paper describes a baseline configuration of the flying wing aircraft analysed in the frame of NACRE PDA project under the umbrella FP6. The main objective of this paper is computing and analysing bending moments corresponding to different scenarios of fuel tanks filled with fuel. As a starting point, the VELA3 configuration was selected basing on geometry and aerodynamic characteristics developed within the VELA project developed in the FP5. A trim fuel tank was proposed additionally as the fifth tank to be able to change CG position, static stability margin and dynamic longitudinal stability. For numerical computing of shear force and bending moment, a very simply linear bending model was proposed. Simulations were performed under the following assumptions: $\mathrm{Mach}=0.85$;

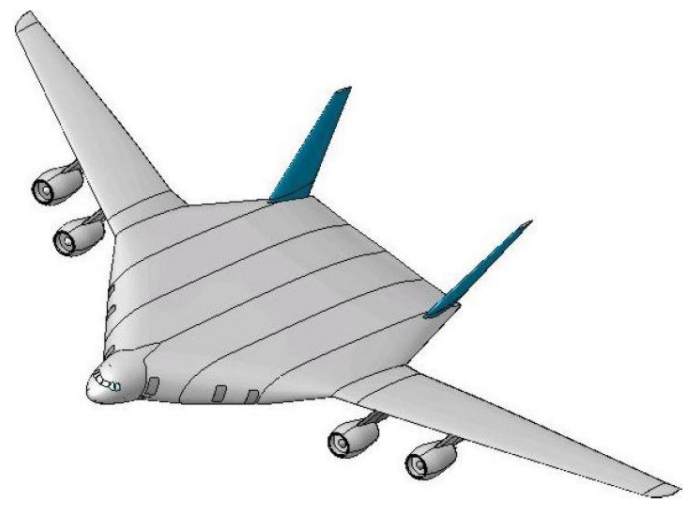

Fig. 4. 3D model of VELA3 [16] 
$C_{L}=0.279$; alpha $=2.8$. As fuel is burned, the aircraft becomes lighter, but Mach number, lift coefficient $C_{L}$ and angle of attack do not change due to the fact the aircraft naturally climbs to a higher altitude of lower density. Details of VELA3 aerodynamic configuration, internal structure and fuel tanks arrangement are shown at Figs. 4-6. Corresponding fuel tank weights are given at Table 1.

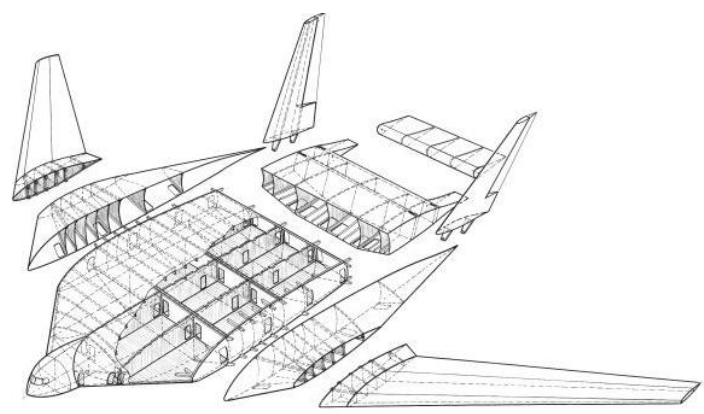

Fig. 5. 3D model of VELA3 - main structure segments [4]

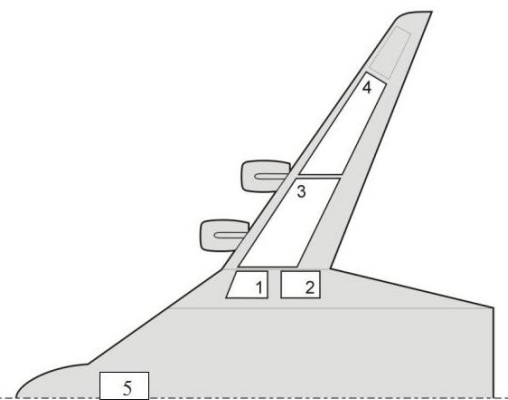

Fig. 6. Fuel tank arrangement. Wing tanks (1-4) and trim tanks (5) are shown

Fuel tank arrangement

\begin{tabular}{|c|c|}
\hline $\begin{array}{c}\text { Fuel tank } \\
\text { number }\end{array}$ & $\begin{array}{c}\text { Fuel tank weight } \\
\text { - right side part } \\
\text { of aircraft only } \\
\text { [tons] }\end{array}$ \\
\hline 1 & 31 \\
2 & 29 \\
3 & 56 \\
4 & 26 \\
5 (trim tank) & $(30)$ \\
\hline & $\begin{array}{c}\Sigma=142 \text { (trim tank } \\
\text { not included) }\end{array}$ \\
\hline
\end{tabular}

Table 1. 


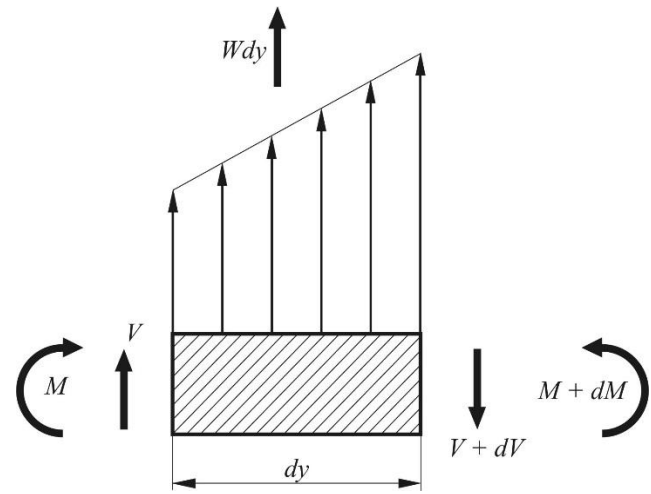

Fig. 7. Beam model of the wing spar showing bending moments and shear forces over an infinitesimal element

For determination of shear loads and bending moments versus wing span, the following external forces will be included into the analysis: aerodynamic load, wing structure weight and fuel weight. Based on the Fig. 7, the resultant load per unit length $[\mathrm{N} / \mathrm{m}]$ as

$$
W=\frac{\mathrm{d} V}{\mathrm{~d} y}
$$

and

$$
V=\frac{\mathrm{d} M}{\mathrm{~d} y},
$$

where $W=L-Q[\mathrm{~N} / \mathrm{m}]$ denote a local wing load; $V[\mathrm{Nm} / \mathrm{m}]-$ shear load and $M$ $[\mathrm{Nm}]$ - bending moment.

Coming from the above differential relations, one can obtain shear load and bending moment distributed along the wing span in the following form [10]

$$
V=\int_{y}^{b / 2} W(y) \mathrm{d} y=\lim _{N \rightarrow \infty} \sum_{i}^{N} W_{i} \Delta y_{i},
$$

and

$$
M=\int_{y}^{b / 2} V(y) \mathrm{d} y=\lim _{N \rightarrow \infty} \sum_{i}^{N} V_{i} \Delta y_{i} .
$$

Basing on the mathematical model (eq.1-4), a number of calculations have been performed. Lift versus span is shown in Fig. 8, after [4]. The most representative cases of geometric characteristics, shear forces and bending moments, all versus wing span, are presented in Figs. 9-17.

Fig. 18 shows dimensionless bending moments. It can be noticed that the smallest bending moments correspond to the case marked by (fuel tank no 4 is full, tanks 1, 2, 3 are empty). The highest bending moment correspond to the case 


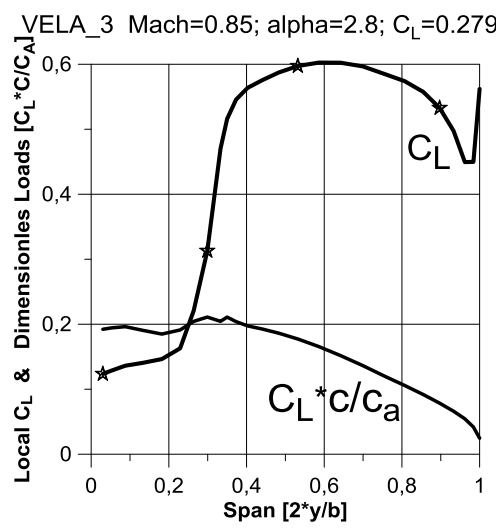

Fig. 8. Spanwise lift distribution and local lift coefficient, from [16]

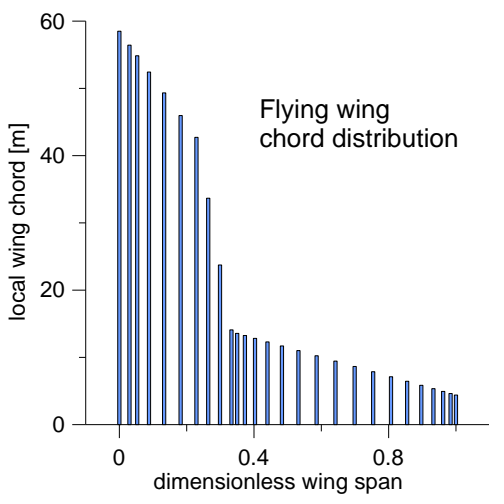

Fig. 9. Flying wing chord spanwise distribution, from [4]

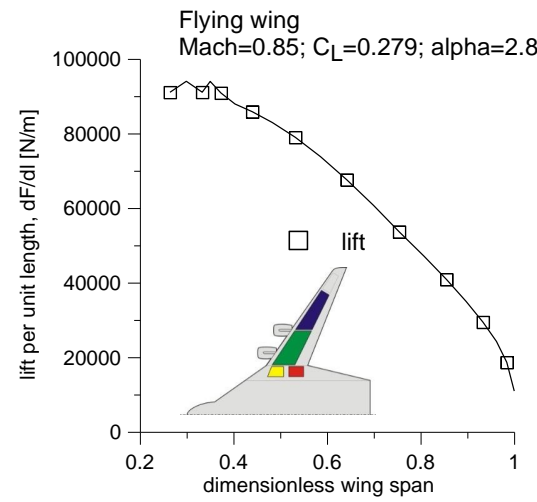

Fig. 11. Lift per unit length, from [4]
Flying wing

wing segment length distribution

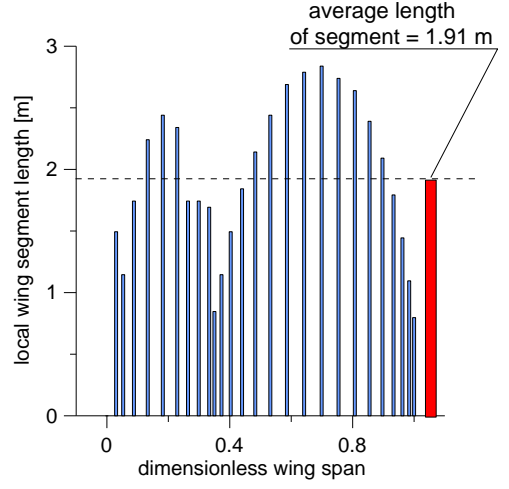

Fig. 10. Flying wing lateral segment length distribution, from [4]

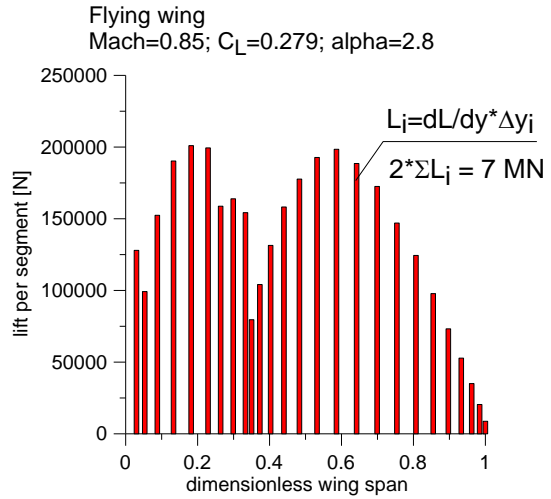

Fig. 12. Lift per segment, from [4] 


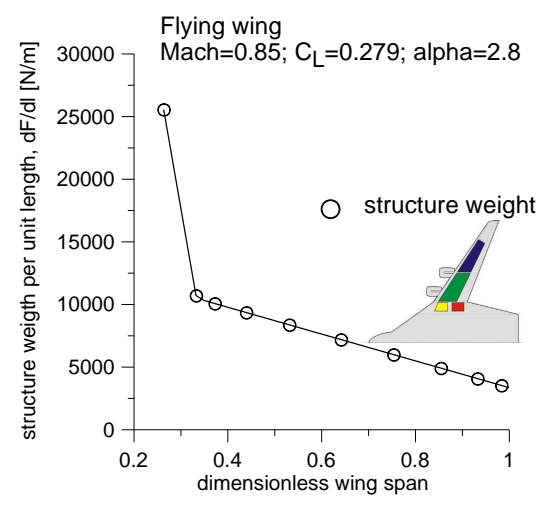

Fig. 13. Structure empty weight per unit length, from [4]

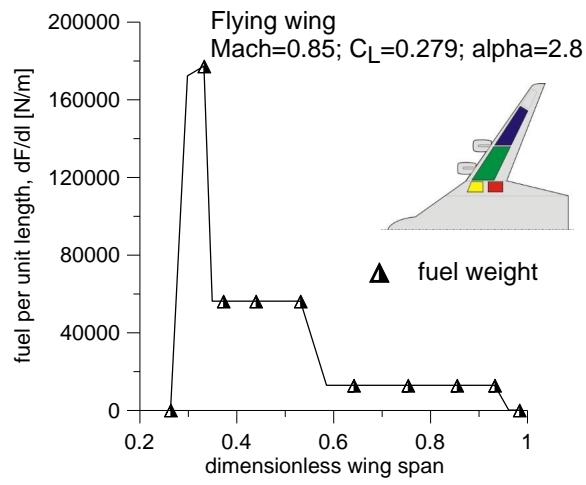

Fig. 15. Fuel weight per unit length, from [4]

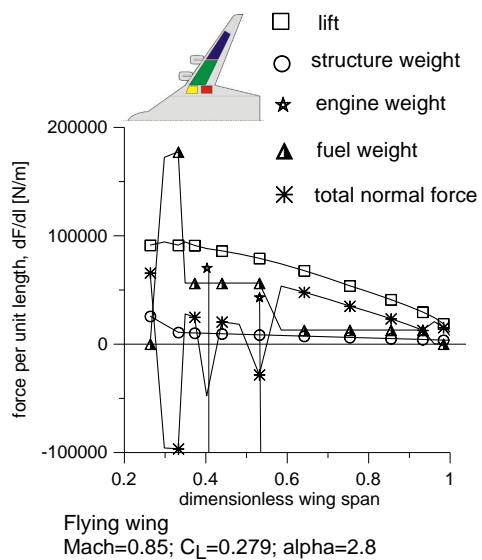

Fig. 17. All components total normal force per unit length, from [4]

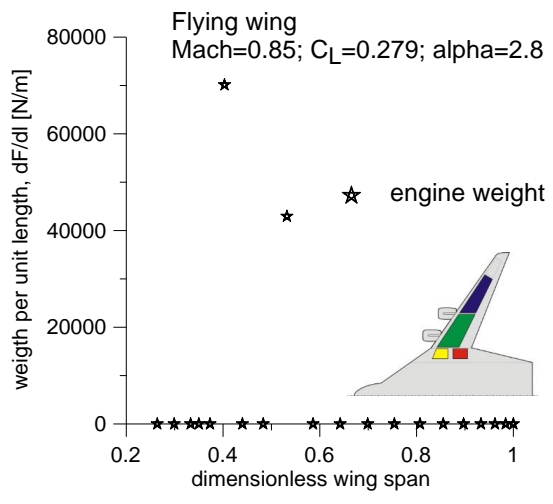

Fig. 14. Engine weight per length of local segment (segments have different lengths), from [4]

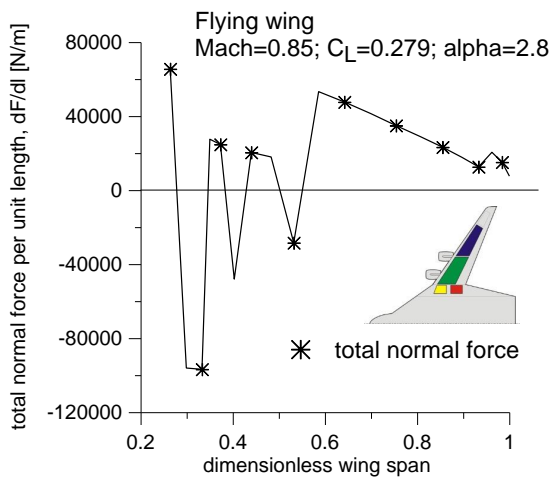

Fig. 16. Total normal force (Lift minus weight of structure+engine+fuel) per unit length, from [4]

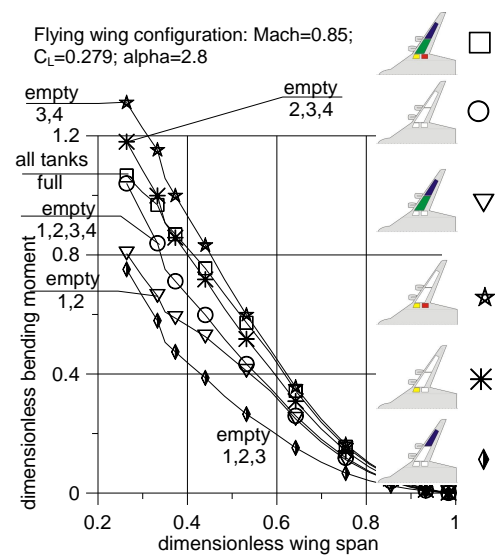

Fig. 18. Comparison of bending moments versus span (from [4]) 


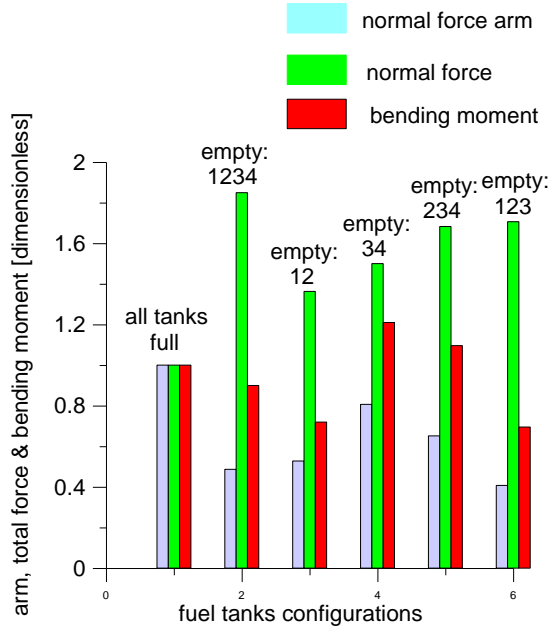

Fig. 19. Comparison of arms, normal forces and moments, from [4]

marked by $\Varangle$ (fuel tanks 1,2 are full, 3, 4 are empty). These results suggest the best scenario of refuelling in flight: start empting the tank no. 1 and 2, then 3 and 4 as the last one. Of course, we do not have any choice at the beginning of the mission and at its end - one must start with all fuel tanks full and to finish with all fuel tanks empty. However, in between one can reduce root bending moment and as a consequence reduce structural wing fatigue.

Table 2 presents flight parameters for different fuel tanks full/empty scenarios. Table 3 shows absolute values of normal force, arms of normal force, shearing forces and bending moments, for all considered fuel tanks full/empty scenarios. The so-called "arm of normal force" gives the lateral position of the centre of wing $\mathrm{CG}$ with respect to the longitudinal plane of aircraft symmetry. Positions of all fuel tanks and values of mass components of fuel tanks, structure and engines are given in Fig. 20 (for example $m_{\mathrm{f} 4}=25 \mathrm{Mg}$ means that fuel tank no 4 has mass equal to

Table 2.

Airplane weight, air density and flight altitude versus fuel tank empting, [4]

\begin{tabular}{|c|c|c|c|c|c|c|}
\hline & A & A & A & A & A & $\stackrel{\text { f }}{\longrightarrow}$ \\
\hline $\begin{array}{c}\text { Fuel mass } \\
{[\mathrm{Mg}]}\end{array}$ & 280 & 0 & 160 & 120 & 60 & 50 \\
\hline $\begin{array}{c}\text { Airplane } \\
\text { mass }[\mathrm{Mg}]\end{array}$ & 700 & 420 & 580 & 540 & 480 & 470 \\
\hline $\begin{array}{c}\text { Air density } \\
{\left[\mathrm{kg} / \mathrm{m}^{3}\right]}\end{array}$ & 0.293 & 0.175 & 0.243 & 0.226 & 0.201 & 0.197 \\
\hline $\begin{array}{c}\text { Flight } \\
\text { altitude }[\mathrm{km}]\end{array}$ & 12.4 & 15.7 & 13.6 & 14.0 & 14.9 & 14.8 \\
\hline
\end{tabular}


Equilibrium of wing represented by beam model [4]

\begin{tabular}{|c|c|c|c|c|c|c|}
\hline $\begin{array}{c}\text { Normal } \\
\text { Force }[\mathrm{kN}]\end{array}$ & 504 & 932 & 687 & 756 & 848 & 860 \\
\hline $\begin{array}{c}\text { Arm of } \\
\text { Normal } \\
\text { force }[\mathrm{m}]\end{array}$ & 44.7 & 28.5 & 29.8 & 38.6 & 33.7 & 26.0 \\
\hline $\begin{array}{c}\text { Shearing } \\
\text { Force }[\mathrm{kN}]\end{array}$ & 504 & 932 & 687 & 756 & 848 & 860 \\
\hline $\begin{array}{c}\text { Bending } \\
\text { moment } \\
{[\mathrm{MNm}]}\end{array}$ & 16.7 & 16.3 & 12.6 & 20.6 & 18.5 & 12.6 \\
\hline
\end{tabular}

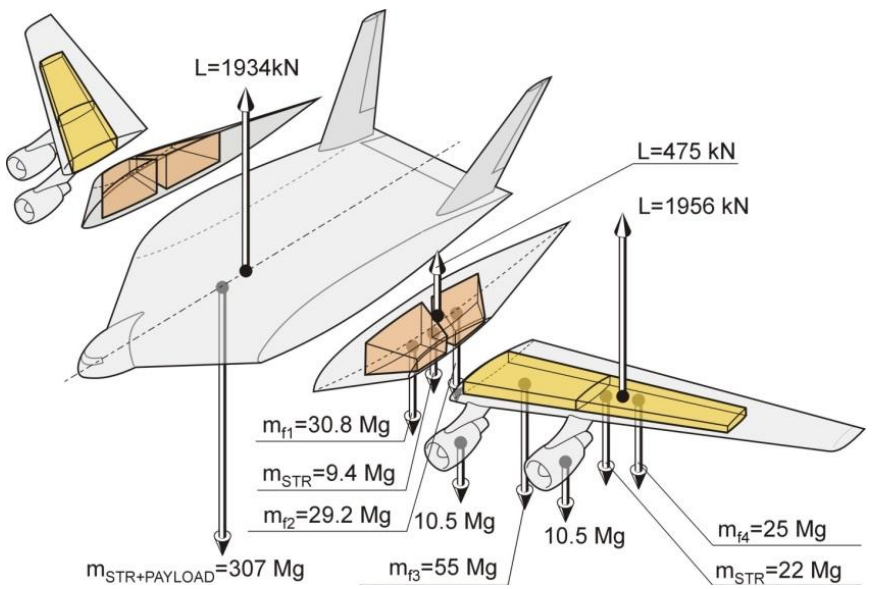

Fig. 20. Forces acting on wing (zero-order approximation), [4]

$25 \mathrm{Mg} ; m_{\mathrm{STR}}=22 \mathrm{Mg}$ means that outer wing segment has mass equal to $22 \mathrm{Mg}$ etc; $1 \mathrm{Mg}=10^{6} \mathrm{~g}$ ). Fig. 21 shows the total (reduced) external force and the point where this force is located.

Fig. 22 presents two different scenarios of tanks empting: 1-2-3-4 and 4-3-2-1. Fig. 22 was obtained under the assumption that aircraft is in long range flight (14 hours), $C_{L}$ is constant and equal to 0.279 , Specific Fuel Consumption is also constant and that overall fuel consumption is equal to 20 tons per 1 hour. It means that successive fuel tanks $(1,2,3,4)$ deliver the fuel for $3 \mathrm{~h}, 2.8 \mathrm{~h}, 5.6 \mathrm{~h}$ and $2.6 \mathrm{~h}$, respectively.

Scenario 1-2-3-4 is more advantageous than scenario 4-3-2-1 because the average stress level in wing structure is lower (approximately $\Delta \mathrm{M} / \mathrm{M} \cdot 100 \%=$ $(1.1-0.8) / 0.8 \cdot 100 \%=37 \%)$. It can influence the rate of fatigue. 


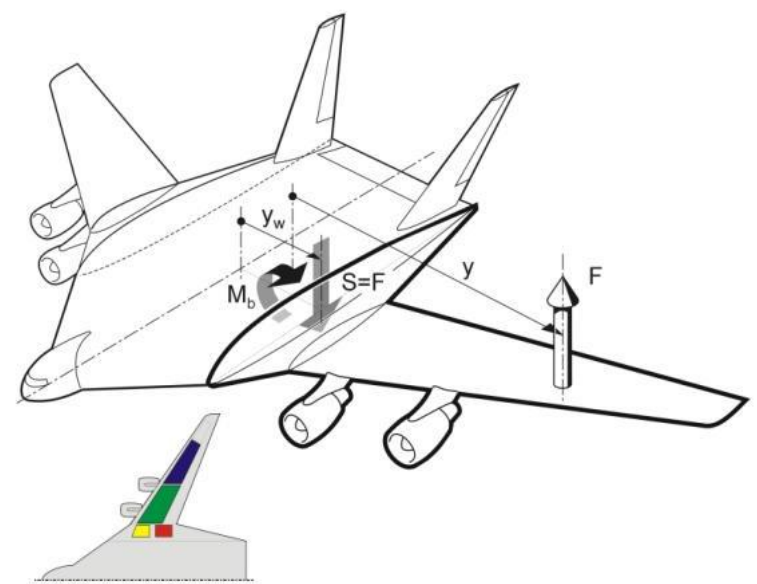

Fig. 21. Wing forces reduced to one wing force $\mathrm{F}$ and bending moment acting at root chord (All tanks are full), [4]

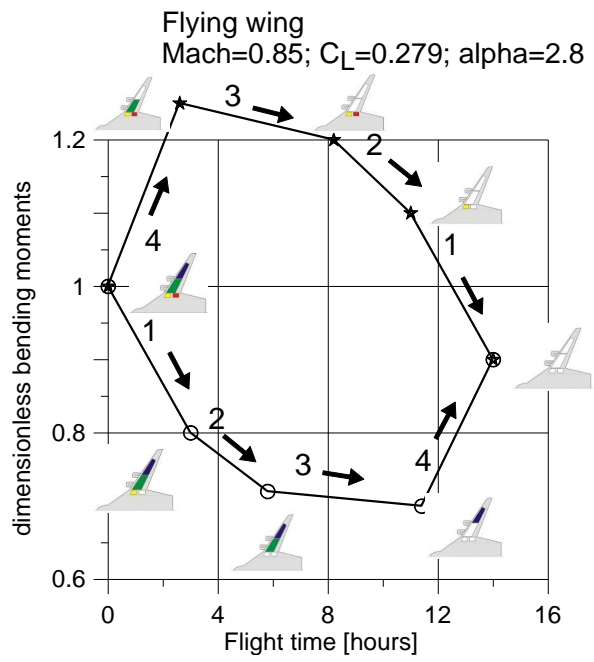

Fig. 22. Dimensionless root bending moment (referred to root the bending moment corresponding to all fuel tanks fully filled-in, equal to $16.7 \mathrm{MNm}$ ) as a function of time in long range flight for 2 different scenarios of tanks empting: 1-2-3-4 and 4-3-2-1

The order of fuel tank empting should start from tanks 1 or 2 (from point of view of the wing bending moments it does not matter if we start empting from tank 1 or 2 , however from a stability point of view it is better if we start empting from tank no. 2 - this was proved in NACRE project [4]), then 3 and the finally we take fuel from tank no. 4. At the beginning (full fuel tanks) and at the end of the mission (empty fuel tanks) we are not able to influence bending moments. But one can decrease the maximum bending moment (scenario 1-2-3-4) and in consequence it is possible to decrease the rate of fatigue. 
Manuscript received by Editorial Board, July 17, 2016;

final version, September 22, 2016.

\section{References}

[1] Z. Goraj and P. Zakrzewski. Aircraft Fuel Systems and Their Influence on Stability Margin. Transactions of the Institute of Aviation, 183:29-40, 2005.

[2] R. Whitford. Fundamentals of Fighter Design. Airlife Publishing Ltd, London 2000.

[3] D. Lombardo. Advanced Aircraft Systems. TAB Books Imprint of McGraw-Hill, New York 1993.

[4] Z.Goraj. Shear force \& bending moment versus fuel distribution. Presentation given at NACRE T2.2 Meeting. Stockholm - FOI, May 2007. NACRE website, unpublished.

[5] International Aviation Safety Association - www.iasa.com.au

[6] R. Langton, Ch. Clark, M. Hewitt and L. Richards. Aircraft Fuel Systems. AIAA Education Series, Wiley, The Atrium, UK, 2009.

[7] J. Roskam. Airplane Design. Part 4, DarCorporation, Lawrence, Kansas 2000.

[8] D. Raymer. Aircraft Design: A Conceptual Approach AIAA Educational Series, AIAA 1992.

[9] E. Torenbeek. Synthesis of Subsonic Airplane Design. Delft University Press 1982.

[10] T. Corke. Design of Aircraft. Prentice Hall 2003.

[11] Boeing B737 - 300/400/500, Maintenance Manual. P.L.L. LOT, 2000.

[12] D. Lombardo. Aircraft Systems. McGraw-Hill, London 1999.

[13] Concise Encyclopedia of Aeronautics \& Space Systems. Editors: M. Pelegrin, W. Hollister, Pergamon Press, Oxford 1993.

[14] CAPECON Project No GRD1-2001-40162 (Civil UAV Applications and Economic Effectivity of Potential CONfiguration Solutions), Technical documents 2002-2004. V FR of European Union.

[15] Z. Goraj. STB - Software for aircraft static and dynamic stability, maneuverability and trim conditions. Warsaw University of Technology, 2002, unpublished.

[16] J. Loerke et.al. NACRE D1.2-5 Publication of Flying Wing Baseline Configuration. NACRE Internal Report - unpublished. Hamburg, October 2006.

\section{Projektowanie i optymalizacja zespołu zbiorników paliwowych dla konfiguracji BWB}

Streszczenie

W pracy przedstawiono założenia, cele, metody, wyniki i wnioski dotyczące układu zbiorników paliwowych dla projektu samolotu pasażerskiego w konfiguracji BWB, t.j. kadłuba przechodzącego płynnie w skrzydło. Zamieszczono krótki przegląd współczesnych układów zbiorników paliwowych, które mogą stanowić punkt wyjściowy do projektu systemu paliwowego dla dużych samolotów pasażerskich. Takie systemy powinny umożliwiać przepompowywanie paliwa w celu zachowania położenia środka masy samolotu w akceptowalnych granicach, ze względu na warunki równowagi oraz stateczności samolotu. Wraz ze wzrostem prędkości środek parcia przesuwa się do tyłu samolotu i dla zachowania równowagi podłużnej zmianie ulega wychylenie sterów wysokości, trymera lub tzw. elewonów. Aby uniknąć nadmiernego wzrostu oporów wyważenia paliwo powinno być przepompowywane ze zbiorników położonych z przodu do zbiorników położonych w tylnej części samolotu. W tym celu obliczono zmianę oporu minimalnego w funkcji położenia środka masy i ciężaru samolotu. Główna część pracy jest poświęcona analizie rozkładu momentów gnących skrzydła w funkcji wypełnienia zbiorników paliwowych. Zbadano kilkanaście różnych wariantów wypompowywania paliwa ze zbiorników w umieszczonych w skrzydle i zminimalizowano wartości momentów gnących 
u nasady skrzydła. Optymalizacje przeprowadzono przy założeniu, że samolot wykonuje długotrwały lot (14 godzin), ze współczynnikiem siły nośnej $C_{L}=0.279$ i przy stałym jednostkowym zużyciu paliwa $(\mathrm{SFC}=20$ ton na $1 \mathrm{godz}=\mathrm{const})$. Stwierdzono, że średni poziom naprężeń w strukturze dźwigara głównego skrzydła jest najmniejszy jeżeli wypompowywanie paliwa rozpocznie się od zbiorników zlokalizowanych jak najbliżej pionowej płaszczyzny symetrii samolotu, czyli u nasady skrzydeł. Minimalizacja naprężeń może mieć istotny wpływ na zmniejszenie zmęczenia dźwigarów. 